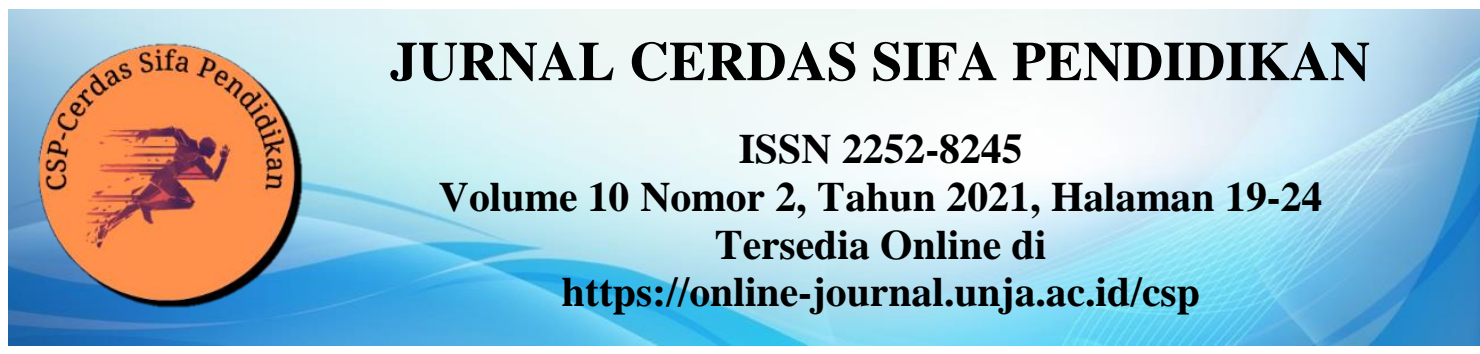

Research Article

OPEN ACCESS

\title{
Sosialisasi Penerapan Indeks Massa Tubuh (IMT) di Suta Club
}

\author{
Mhd Usni Zamzami Hasibuan ${ }^{1}$ Palmizal. A $^{2}$, \\ Program Studi Kepelatihan Olahraga, FKIP, Universitas Jambi. Indonesia ${ }^{12}$. \\ Correspondence Author : zamzamihsb16@unja.ac.id ${ }^{2}$
}

\begin{abstract}
ABSTRAK
Tubuh yang ideal menjadi salah satu hal yang diidamkan bagi setiap orang, baik itu pria dan wanita. Terkadang penampilan mampu memberikan pengaruh positif dalam kegiatan sehari-hari, terlebih setelah sekarang kita sudah diperbolehkan pemerintah untuk melakukan aktifitas diluar rumah dengan tetap menjaga protokol kesehatan. Namun demikian bukanlah suatu hal yang mudah untuk mengembalikan tubuh yang ideal setelah sekian lama mengkonsumsi makanan tanpa ada pembakaran kalori yang maksimal. Suta club merupakan sanggar yang beranggotakan wanita yang rata-rata memiliki masalah dengan berat badan. Tidak sedikit yang beranggapan bahwa dengan senam yang rutin mampu memperbaiki penampilan fisik, akan tetapi perlu digaris bawahi bahwa dalam melakukan aktifitas fisik memerlukan suatu alat sederhana yang mampu membantu untuk memantau setiap perkembangan penurunan berat badan tersebut demi penampilan yang sesuai dengan harapan atau target yang ingin dicapai. Indeks Massa Tubuh (IMT) adalah suatu alat yang sederhana untuk dapat membantu setiap individu dalam memantau status kondisi tubuh dan sangat erat kaitannya dengan kelebihan atau kekurangan berat badan.
\end{abstract}

Kata Kunci: Berat Badan Ideal, Indeks Massa Tubuh.

\section{Socialization of The Application of Body Mass Index at Suta Club}

\begin{abstract}
The ideal body is one of the things that everyone desires, both men and women. Sometimes appearance is able to have a positive influence in daily activities, especially now that we are now allowed by the government to carry out activities outside the home while maintaining health protocols. However, it is not an easy thing to restore the ideal body after consuming food for a long time without burning maximum calories. Suta club is a studio consisting of women who on average have problems with weight. Not a few think that regular exercise can improve physical appearance, but it should be underlined that in carrying out physical activity requires a simple tool that can help to
\end{abstract}


monitor any progress in weight loss for the sake of an appearance that is in line with expectations or targets to be achieved. . Body Mass Index (BMI) is a simple tool that can help every individual in monitoring the status of body condition and is closely related to being overweight or underweight.

Keywords: Ideal Body Weight, Body Mass Index.

\section{PENDAHULUAN}

Dunia digemparkan oleh virus covid 19 yang banyak merenggut banyak jiwa sehingga seluruh penduduk diseluruh dunia diperintahkan oleh pemerintah untuk menghentikan aktifitas diluar rumah dan untuk tetap berada dirumah demi memutus rantai penyebaran virus covid 19. Selama didalam rumah begitu banyak aktifitas yang biasanya dilakukan diluar rumah harus terhenti, salah satunya aktifitas yang berkenaan dengan fisik. Kegiatan didalam rumah cenderung terbatas sehingga membuat setiap individu menjadi lebih sedikit dalam aktifitas gerak yang mengarah kepada unsur fisik.

Obesitas merupakan salah satu manifestasi dari masalah gizi lebih, yang perlu mendapatkan perhatian. Obesitas merupakan keadaan berlebihnya lemak tubuh secara absolut maupun relatif. Banyak faktor yang berperan dalam terjadinya obesitas yang Sebagian besar merupakan interaksi antara faktor genetic dengan faktor lingkungan, antara lain aktivitas fisik, sosial ekonomi, dan nutrisi. Keadaan obesitas meningkatkan risiko penyakit-penyakit kardiovaskular karena keterkaitanya dengan sindrom metabolic atau sindrom resistensi insulin/hiperinsulinemia, intoleransi glukosa/Diabetes Melitus (DM),dyslipidemia, hipertensi dan lainnya. Obesitas adalah penumpukan lemak yang berlebihan atau abnormal yang dapat menggangu kesehatan (WHO,2017). Penyebab utama terjadinya obesitas yaitu ketidakseimbangan antara asupan energi dengan pengeluaran energi (Betty, 2004). Obesitas adalah kondisi yang ditandai gangguan keseimbangan energi tubuh yaitu terjadi keseimbangan energi positif yang akhirnya disimpan dalam bentuk lemak di jaringan tubuh (Nelm, et, al 2011).

Tubuh yang ideal menjadi salah satu hal yang diidamkan bagi setiap orang, baik itu pria dan wanita. Terkadang penampilan mampu memberikan pengaruh positif dalam kegiatan sehari-hari, terlebih setelah sekarang kita sudah diperbolehkan pemerintah untuk melakukan aktifitas diluar rumah dengan tetap menjaga protokol kesehatan. Namun demikian bukanlah suatu hal yang mudah untuk mengembalikan tubuh yang ideal setelah sekian lama mengkonsumsi makanan tanpa ada pembakaran kalori yang maksimal. Tubuh ideal adalah dambaan semua orang, baik laki-laki maupun perempuan. Menurut (Puspasari, L. 2019) tubuh ideal adalah tubuh yang relatif proporsional dengan tinggi badan, atau secara umum dapat dikatakan tidak gemuk dan juga tidak kurus. Proporsi ideal ini dapat dihitung dengan menggunakan Indeks Massa Tubuh (IMT), yaitu angka penilaian standar berdasarkan proporsi perbandingan tinggi badan dan berat badan, sehingga dapat dikategorisasikan dalam golongan normal, kurang, berlebih, atau obesitas.

MT atau sering juga disebut indeks Quatelet pertama kali ditemukan oleh seorang ahli matematika Lambert Adolphe Jacques Quatelet adalah alat pengukuran komposisi tubuh yang paling umum dan sering digunakan. Beberapa studi telah mengungkapkan bahwa IMT adalah alat pengukuran yang berguna untuk mengukur obesitas, dan telah direkomendasikan untuk evaluasi klinik pada obesitas anak (Daniels et al, 1997).Indeks Massa Tubuh (IMT) adalah suatu alat yang 
sederhana untuk dapat membantu setiap individu dalam memantau status kondisi tubuh dan sangat erat kaitannya dengan kelebihan atau kekurangan berat badan. Indeks Massa Tubuh (IMT) adalah cara sederhana untuk melihat apakah orang tersebut kelebihan atau kekurangan berat badan. Indeks Massa Tubuh (IMT) atau yang lebih dikenal dengan indeks Quetelet, merupakan perhitungan lemak tubuh manusia berdasarkan berat badan dan tinggi seseorang. Indeks Massa Tubuh (IMT) merupakan rumus matematis yang dinyatakan sebagai berat badan (dalam kilogram) dibagi dengan kuadrat tinggi badan (dalam meter). IMT adalah cara termudah untuk memperkirakan obesitas serta berkolerasi tinggi dengan massa lemak tubuh, selain itu juga penting untuk mengidentifikasi pasien obesitas yang mempunyai risiko komplikasi medis (Pudjiadi et al, 2010)

\section{METODE}

Program sosialisasi pemahaman indeks massa tubuh bertujuan untuk menambah wawasan dan pengetahuan anggota Suta Club yang ingin mendapatkan tubuh yang ideal dengan mengontrol melalui perhitungan sederhana. Program tersebut dilaksanakan dengan pemaparan melalui powerpoint, setelah pemaparan tersebut selesai dilanjutkan dengan sesi praktik penghitungan indeks massa tubuh masing-masing daripada anggota Suta Club tersebut.

Penyampaian materi dalam pemaparan juga membahas fungsi dari indeks massa tubuh dalam dunia Kesehatan. Penggunaan indeks massa tubuh adalah sebagai salah satu alat deteksi yang bisa menandakan apakah berat badan seseorang termasuk dalam kategori normal, kurang, kelebihan, atau bahkan obesitas. Kekurangan dan kelebihan berat badan sama-sama dapat memberikan resiko yang besar pada Kesehatan.

Mereka yang kelebihan berat badan dan obesitas beresiko terkena penyakit diabetes tipe 2, tekanan darah tinggi, dan gangguan kardiovaskular, sedangkan seseorang yang berat badannya kurang atau dibawah batas ideal beresiko mengalami malnutrisi, osteoporosis dan anemia.

1. Cara Menghitung Indeks Massa Tubuh (IMT)

Untuk menghitung Indeks Massa Tubuh (IMT) diperlukan mengukur berat dan tinggi badan. Untuk itu diperlukan alat untuk mengukur berat dan tinggi badan. Berat badan dinyatakan dalam satuan kilogram dan tinggi badan dikuadratkan.

Rumus :

$$
\mathrm{IMT}=\frac{\text { Berat Badan }(\mathrm{kg})}{\text { kuadrat Tinggi Badan }\left(\mathrm{m}^{2}\right)}
$$

2. Kategori Indeks Massa Tubuh

Tabel Kategori Indeks Massa Tubuh (IMT)

\begin{tabular}{|c|c|c|}
\hline \multirow[t]{2}{*}{ Kurus } & Kekurangan berat badan tingkat berat & $<17,0$ \\
\hline & Kekurangan berat badan tingkat ringan & $17,0-18,4$ \\
\hline \multirow[t]{2}{*}{ Normal } & & \\
\hline & & $18,5-25,0$ \\
\hline \multirow[t]{2}{*}{ Gemuk } & Kelebihan berat badan tingkat ringan & $25,1-27,0$ \\
\hline & Kelebihan berat badan tingkat berat & $>27,0$ \\
\hline
\end{tabular}

Sumber P2PTM Kemenkes RI 
Langah-Langkah Kegiatan

1. Menyiapkan materi pemaparan untuk sosialisasi penerapan Indeks Massa Tubuh (IMT) di Suta Club.

2. Memberikan teknik penghitungan Indeks Massa Tubuh dan evaluasi dari masingmasing hasil yang diperoleh untuk memaksimalkan target atau capaian yang ingin diraih oleh anggota suta club

\section{HASIL DAN PEMBAHASAN}

IMT adalah cara perhitungan status gizi dengan membandingkan berat badan dengan tinggi badan dalam satuan $\left(\mathrm{kg} / \mathrm{m}^{2}\right)$. IMT yang baik menunjukkan pemenuhan nutrisi yang optimal. Jumlah IMT dipengaruhi oleh beberapa hal seperti asupan nutrisi, pola makan, aktivitas fisik, gaya hidup, status sosial-ekonomi, tingkat pendidikan, tingkat pengetahuan, keadaan lingkungan, paparan penyakit kronis dan persentase lemak. Semakin tinggi asupan nutrisi maka semakin tinggi kemungkinan seseorang mengalami peningkatan IMT. Asupan nutrisi ini dipengaruhi oleh pola makan, tingkat Pendidikan dan pengetahuan, status sosial-ekonomi. Semakin sering seseorang makan, maka makin tinggi pula asupan nutrisinya, begitu pula dengan tingkat pendidikan dan pengetahuan yang berpengaruh terhadap jenis makanan yang di konsumsi. Tingginya status sosial-ekonomi juga dapat meningkatkan daya beli seseorang untuk memenuhi kebutuhan nutrisinya. Tingkat pendidikan, pengetahuan dan tingkat sosial- ekonomi juga dapat mempengaruhi gaya hidup dan aktivitas seseorang sehari-hari dan akhirnya mempengaruhi IMT.

Hasil yang dicapai dalam pengabdian ini adalah berupa pemahaman tentang bagaimana cara mengetahui pada kategori apa berat badan dengan cara menghitungnya berdasarkan rumus indeks massa tubuh. Selain mendapatkan pemahaman dan wawasan mengenai bagaimana cara penghitungan indeks massa tubuh, kegiatan ini juga menghasilkan materi yang dapat dijadikan pegangan dan dibagi kepada siapapun yang inign mengetahui indeks massa tubuhnya, dan metode ini sangatlah mudah untuk dipahami dan diaplikasikan. Adapun komponen Indeks Massa Tubuh sebagai berikut:

a. Tinggi Badan

Tinggi badan diukur dengan posisi berdiri tegak lurus, tanpa menggunakan alas kaki dengan kedua tangan di samping badan dan punggung menempel ke dinding, serta pandangan ke arah depan.

b. Berat Badan

Waktu yang paling baik dalam menimbang berat badan adalah pada pagi hari sebelum sarapan pagi dengan catatan telah melakukan pengosongan lambung selama 10-12 jam. Lakukan penimbangan berat badan dengan pakaian yang berbahan ringan dan berada di titik tengah timbangan.

1. Usia

Ada beberapa faktor yang mempengaruhi indeks massa tubuh, yaitu :

Pada dasarnya setiap orang akan mengalami penambahan usia, akan tetapi dengan penambahan usia justru orang tersebut semakin jarang berolahraga. Jika setiap orang jarang berolahraga maka akan mempengaruhi kenaikan berat badannya sehingga memiliki dampak terhadap indeks massa tubuh.

2. Jenis Kelamin

Indeks Massa Tubuh dengan kategori obesitas ( berat badan berlebihan ) lebih banyak ditemukan pada pria. Namun berdasarkan data National Health and Nutrition 
Examination Survey (NHANES) menunjukkan tingkat obesitas pada wanita lebih besar daripada pria di Amerika.

3. Pola Makan

Pengulangan susunan makanan disebut sebagai pola makan, Pola makan yang buruk akan berdampak sangat signifikan terhadap kenaikan berat badan. Obesitas sangat mudah terjadi jika mengkonsumsi makanan siap saji yang mana banyak terkandung lemak dan gula yang tinggi pada makanan siap saji tersebut. Selain itu, penambahan porsi makan dan pengaturan jam makan yang tidak tetap juga merupakan salah satu indikator pencapaian obesitas.

4. Berat Badan

Jika seseorang memiliki berat badan yang berlebihan, maka itu juga dapat mempengaruhi indeks massa tubuhnya. Semakin berat dan terus mengalami kenaikan berat badan maka itu sangat berdampak terhadap indeks massa tubuh orang tersebut.

5. Aktifitas fisik

Apabila seseorang memiliki aktifitas fisik yang baik, maka tubuh menjadi lebih sehat dan berpengaruh positif terhadap indeks massa tubuh agar mendapatkan hasil yang normal. Berbanding terbalik jika aktifitas fisik menurun, itu sangat berdampak negatif terhadap indeks massa tubuh seseorang.

Pada kegiatan sosialisasi indeks massa tubuh ini diharapkan agar dapat mengembangkan materi pada penyusunan program penurunan berat badan sesuai dengan tipe tubuh, usia, dan aktifitas harian yang dilakukan setiap anggota Suta Club.

\section{SIMPULAN}

Dari kegiatan sosialisasi indeks massa tubuh, dapat ditarik kesimpulan bahwa dengan kegiatan sosialisasi indeks massa tubuh memberikan dampak positif, dilihat dari antusias anggota senam yang mendengarkan pemaparan sosialisasi tersebut. Anggota sanggar senam yang mengikuti sosialisasi dapat memahami setiap tahapan dari materi yang disampaikan. Dengan adanya sosialisasi indeks massa tubuh ini mampu membantu seluruh anggota sanggar senam dalam memahami kondisi yang mereka alami saat ini. Dengan adanya sosialisasi indeks massa tubuh ini, diharapkan kepada seluruh anggota lebih semangat dalam menjaga komposisi tubuh yang ideal sesuai dengan target yang telah ditetapkan.

\section{DAFTAR RUJUKAN}

Adam JMF, Adam FMS, Adrianjah H. Penatalaksanaan Penderita Sindrom Metabolik. Medika Jurnal Kedokteran dan Farmasi. 2004;12:778-82

Asmadi. Konsep dan Aplikasi Kebutuhan Dasar Klien. Jakarta: Salemba Medika, 2009.

Greve J., Alonso A., Ana., Bordini P. G and Camanho L. G. Correlation Between Body Mass Index And Postural Balance. Clinics 2007;62(6):717-20

Hariadi, Ali Ar. Hubungan Obesitas dengan beberapa faktor Risiko Penyakit Jantung Koroner. Jurnal Kesehatan, 2005;12(1):58-67

Morris C, Jacqueline. Pedoman Gizi Pengkajian dan Dokumentasi. Jakarta: EGC, 2013. 
Octari C, Liputo NI, Edison. Hubungan Status Sosial Ekonomi dan Gaya Hidup dengan Kejadian Obesitas pada Siswa SD Negeri 08 Alang lawas Padang. Diambil dari: http://jurnal.fk.unand.ac.id, 26 November 2021.

Puspasari, L. (2019). Body Image dan Bentuk Tubuh Ideal, Antara Persepsi dan Realitas. Buletin Jagaddhita, 1(3), 1-4.

Sari RI. Faktor yang berhubungan dengan status gizi remaja usia 12-15 tahun di Indonesia tahun 2007 ( analisis data sekunder Riskesdas tahun 2007 ) (skripsi). Jakarta: Fakultas Kesehatan Masyarakat Universitas Indonesia, 2012.

Sayogo S. Gizi remaja putri. Jakarta: Balai Penerbit FKUI, 2006.

Soetjiningsih. Tumbuh kembang remaja dan permasalahannya. Jakarta: CV Sagung Seto, 2004.

Syaifuddin. Fisiologi Tubuh Manusia Edisi 2. Jakarta: Salemba Medika, 2009. 